\title{
Prelude to America's Downfall: The Stagflation of the 1970s
}

\author{
Vassilis K. Fouskas \\ University of East London, London, Great Britain \\ 凹v.fouskas@uel.ac.uk
}

\begin{abstract}
Since the end of the Bretton Woods system and the stagflation of the 1970s, the transatlantic core, under the leadership of the United States of America, has been trying to expand its model of free market capitalism embracing every part of the globe, while addressing its domestic overaccumulation crisis. This article follows a historical methodological perspective and draws from the concept of Uneven and Combined Development (UCD), which helps us consider the structural reasons behind the long and protracted decline of the American economic power. In this respect, according to the UCD concept, there is no global power that can enjoy the privilege for being at the top of the global capitalist system forever in a world which develops unevenly and in a combined way. Power shifts across the world and new powers come to challenge the current hegemonic power and its alliance systems. The novelty of the article is that it locates this decline in the 1970s and considers it as being consubstantial with the state economic policy of neo-liberalism and financialisation (supply-side economics). However the financialised capitalism of the transatlantic assemblage lack industrial base producing, reproducing and recycling real commodity values. Further, the article shows that this attempt to remain at the top of the global capitalist system forever has not been successful, not least because the regime which the recovery of the core had rested upon, that of neo-liberal financialisation represents a major vulnerability of the transatlantic assemblage eroding the primacy of the United States of America in it.
\end{abstract}

Key words: neo-liberal financialisation, financial statecraft, China, USA, Great Recession, stagflation

For citation: Fouskas, V.K. (2021). Prelude to America's Downfall: The Stagflation of the 1970s. Vestnik RUDN. International Relations, 21(2), 243-251. https://doi.org/10.22363/2313-0660-2021-21-2-243-251

\section{Начало падения Америки: стагфляция 1970-х гг.}

\author{
В.К. Фускас \\ Университет Восточного Лондона, Лондон, Великобритания \\ 凶v.fouskas@uel.ac.uk
}

\begin{abstract}
Аннотация. С момента краха Бреттон-Вудской системы и стагфляции 1970-х гг. трансатлантическое ядро под руководством Соединенных Штатов Америки пыталось расширить свою модель капитализма свободного рынка, охватив все части земного шара, и в то же время урегулировать внутренний кризис чрезмерного накопления. Автор следует исторической методологической перспективе и опирается на концепцию неравномерного и комбинированного развития (НКР), которая помогает рассмотреть структурные причины длительного и продолжительного упадка американской экономической мощи. Вместе с тем, согласно концепции НКР, в мире, развивающемся неравномерно и комбинированно, не существует мировой державы, которая единолично занимает лидирующие позиции в глобальной капиталистической системе. Смена власти по всему миру и новые страны бросают вызов современному гегемонистскому государству и системе его союзников. Новизна исследования заключается в том, что она относит спад
\end{abstract}

(C) Fouskas V.K., 2021

This work is licensed under a Creative Commons Attribution 4.0 International License.

https://creativecommons.org/licenses/by/4.0/ 
американской экономической мощи к 1970-м гг. и рассматривает его в контексте государственной экономической политики неолиберализма и финансиализации (экономика предложения). При этом основной проблемой финансового капитализма трансатлантического объединения является отсутствие промышленной базы для производства, воспроизводства и переработки сырьевых товаров. Отмечается, что попытка этих стран навсегда остаться на вершине глобальной капиталистической системы не увенчалась успехом, в особенности из-за режима, на котором базировалось восстановление ядра - неолиберальной финансиализации. Сделан вывод, что неолиберальная финансиализация угрожает трансатлантическому объединению, подрывая в нем первенство Соединенных Штатов Америки.

Ключевые слова: неолиберальная финансиализация, управление государством посредством финансов, Китай, США, Великая рецессия, стагфляция

Для цитирования: Fouskas V.K. Prelude to America's Downfall: The Stagflation of the 1970s // Вестник Российского университета дружбы народов. Серия: Международные отношения. 2021. Т. 21. № 2. C. 243 -251. DOI: $10.22363 / 2313-0660-2021-21-2-243-251$

\section{Introduction}

This short article defines "globalisation" as "financialisation". Primarily, this is because finance was the first sector in the post-Bretton Woods era of floating exchange rates that was truly globalised. "Closing the gold window", as was characteristically put [Gowa 1983], was a conscientious decision taken by US state elites to solve a lingering balance of payment crisis that appeared in the early 1960s. Secondarily, this is because finance and fictitious commodity markets have dominated the political economies of the transatlantic assemblage since the 1980s, when supply-side neoliberal policy-making became embedded displacing Keynesian aggregate demand management along with the manufacturing sector and Fordist wages [Glyn 2007; Gowan 1999]. Thus, financialisation is neo-liberal and was initiated and led by the US state. As a Council on Foreign Relations publication suggests, financial statecraft is "the active participation of the US state's monetary institutions in facilitating new forms of global capital flows" that, by and large, were dormant since the 1930s (securities, asset management, derivatives and futures, credit default swaps and collateralized debt obligations, portfolio investment, special vehicles, etc.) [Steil, Litan 2008].

My narrative follows a historical methodological perspective and draws from the concept of uneven and combined development (see below). This approach has assisted the research design in that it made clear the structural asymmetries of global accumulation processes and their contradictions. The various data from the sources reviewed here are crosschecked against contemporary macroeconomic data. The argument put forth is that neo-liberal financialisation constitutes a major vulnerability of the US system of global power, undermining its primacy and giving way to its sheer competitors, first and foremost China, but also Russia and India. Although there is no space here to examine in detail the grounding of China in the global political economy or how the EU/Eurozone can offer a response to its own existential crisis especially in the midst of the COVID-19 pandemic, the driving structural force of uneven and combined development (UCD) in bringing about such drastic change in the global distribution of power should be factored in. UCD, a notion first developed by Russian Marxist revolutionary Leon Trotsky, is defined as a "loosely articulated web of events, actors and processes developing at different speeds, whose individual courses were interconnected in labyrinthine ways" [Tooze 2015: 29; Rosenberg 2010].

To sum up, this essay maintains that US primacy has been eroded, first, by an internal competitive constraint combining the antagonistic economic correlation between Japan, West Germany and the USA during the "Golden Age of Capitalism" [Marglin, Schor 1992; Hobsbawm 1995]; and then by China's economic rise since the 1990s, adding on another competitive constraint. The structural driving force of these developments has been UCD empowered and guided by the state, whether Chinese, Japanese, German or American. 


\section{Two Phases of Financialisation / Globalisation}

Neo-liberal financial statecraft marks a historical phase of capitalist modernity that pertains to a double transformation: first, it aims at transforming the internal environment of the state via the public policy of neoliberalism, for Anglo-Saxon states, and ordoliberalism for European Economic Community / European Community / European Union / Eurozone states; second, it transforms the external environment of it via the liberalisation of the exchange rate mechanism, the opening-up of money/financial markets and the transnationalization/globalisation of the corporation. Both transformations are feeding each other ${ }^{1}$.

In this new dialectic of national / international, the transformation of the global multinational corporation (American, Japanese, and European) is very important. A key feature of the new global corporation is that it takes advantage of technological innovation, relinquishes the Fordist model of mass production for mass consumption and, in its search to discover cheap labour markets and favourable taxation regimes, creates polygonal supply chains and networks of production, assemblage, circulation and consumption across the entire globe [Dicken 2007; Fouskas, Gökay 2012].

Joint transnational ventures and mergers and acquisitions become the new norm. The aim is the augmentation of profitability by way of making up the losses incurred under the previous Keynesian / Fordist regime of fixed exchange rates and solid industrial economic growth what came conventionally to be called as the "Golden Age of Capitalism". Returns and assets,

1 Both "neo-liberalism" and "ordoliberalism" are supply-side public policies. Nevertheless, the former applies more pertinently to Anglo-American contexts, whereas the latter to the German-Austrian ones. As we have shown elsewhere, Germany managed to transplant its ordoliberal model of capital accumulation onto the EU / Euro-zone [Fouskas, Gökay 2019]. The ordoliberal model is more disciplinarian than the neo-liberal one, insists on a strict de-politicisation of social economy and on a strict separation of the central banking mechanism from political and trade union influences. I touch upon ordoliberalism below. however, tend to be increasingly financialised and often dollarized - as the dollar was freed of its gold fetter and investors realised that speculation on paper assets denominated in dollars is more profitable than employing unionised workers handing out full-time contracts and high (Fordist) wages [Foster, Magdoff 2009].

It should be noted, that neo-liberal financial statecraft was and remains a project structured, primarily, along the reproductive expansionary needs of the American empire-state and comes as a response to the overaccumulation crisis of the $1970 s^{2}$. This crisis, unlike the Great Recession of 2008, manifested itself in the real economic sector, especially in industry. The overaccumulation crisis of the 1970 s was caused by multiple factors - strong social and trade union movements, the erosion of America's gold reserves, the Vietnam war, etc. - and was captured, to a great degree, by debates and arguments developed, among others, by researchers and politicians Alexander Callinicos, Leo Panitch, Giovanni Arrighi, Justin Rosenberg and Robert Brenner [Rosenberg 2001; Arrighi 2007; Brenner 2006; Panitch, Gindin 2013; Callinicos 2009].

Nevertheless, what seems to me as the most prominent factor is the structural force of UCD in the core capitalisms of Europe, Japan and the USA. This form of competitive constraint in the 1970s drove down the (average) rate of profit over a period of years, forcing industrialists to inflate the economy, seek state support and, eventually, to financialise as the decline in profitability was sustained and persistent [Armstrong, Glyn, Harrison 1984: 257]. Importantly, at the time, the markets of the global South were relatively closed due to anticolonial struggles, import substituting policies (Brazil, Argentina) and the rise of Baathist socialism in the Middle East (Egypt, Syria, Iraq). Similarly, the Soviet bloc and China could not offer free markets to the West to support its recovery from its overaccumulation crisis [Sanchez-Sibony 2014].

2 The stagflation is economic stagnation accompanied by high inflation. 
From the early 1960s onwards the USA began registering a balance of payments deficit, not least because other members of the core, such as France, began exchanging their surplus dollars with US gold reserves, as gold remained a tradable commodity. This, brought the Bretton Woods system to its knees, forcing the Nixon administration to get rid of the gold fetter and devalue the US dollar, placing essentially the entire global political economy on a pure dollar standard, especially after the US-Saudi agreement of 1973 - 1974, which stipulated that oil should be traded in dollars only [Fouskas, Gökay 2005].

Thus, neo-liberal financial statecraft is essentially a project driven by the American state in its hub-and-spoke hierarchical articulation with other subordinate political economies of the global core and the global periphery. The interest rate hike engineered by the former head of the American Federal Reserve System (Fed), Paul Volcker, causing havoc in the debt markets of Latin America and (communist) Eastern Europe, should be seen as representing the culmination of the first period of the statecraft (1971-1990). Moreover, the relentless drive to open up East European markets to American and European capital, a process explained by British professor Peter Gowan, stems precisely from the need of the saturated capitals of the core to expand globally, overcoming their overaccumulation crisis at home [Gowan 1999].

Having said this, the big "success" for the USA came during the second period of financial statecraft (1990-2007), which ended up in the Great Recession of 2007-2008. This period embraced mortgage markets (housing) and massive involvement of the shadow banking sector. Further, the project, having as key operational offshore hubs the Wall Street and the City of London, was assisted by the opening-up of East European markets in the wake of the collapse of "really-existing socialism". As the "Volcker shock" came to a halt signalling the end of the first period of the statecraft (1971-1990), the American Fed ushered in an era of low interest rates, which drove up the price of stocks and bonds. These were "owned exclusively", as professor of history Robert Brenner put it, "by the very rich"3.

The creation of this new cross-border financial oligarchy in the transatlantic area headed by US financial capital and extended with myriad of tentacles via the global proliferation of banking, accounting, insurance and other financial services, severely side-lined the power of industrial capital and the real economic sector of the core. With the partial exceptions of Germany and Japan, the manufacturing base of the core since the 1980s has been shrinking. Today's manufacturing base of Britain and the USA stand at $8.8 \%$ and $11.1 \%$ of their respective GDP (but it is $21 \%$ in Germany and $20.8 \%$ in Japan) [Fouskas, Gökay 2019].

No accident, the Western economies as a whole have since the 1970s entered a period of "long downturn", that is a period of slow and protracted decline of their real economic sector, which could not be matched by periods of financial euphoria, such as that of 1991-2007 the second period of financial statecraft that corresponds to low interest rates. When credit was cheap, hence accessible, demand was financed by increased borrowing, creating unsustainable levels of consumer (and other) debt [Alele 2020].

Further, the financial oligarchy packaged, rated, priced and sold this and other forms of debt and paper assets across the globe - such as that resulting from retained profits - in a delirium of grotesque profiteering and speculation creating an unsustainable financialisation chain. Most part of this fictitious capital had not trickled down to the real economic sector as investments in production and infrastructure, especially since the global (western) corporation was migrating to the "global East and South" (China, India, Brazil, South Africa, and Turkey).

\section{How Financialisation Erodes US Primacy}

There are arguments that downplay financialisation as a fundamental component of

\footnotetext{
${ }^{3}$ Brenner R. Editorial: Introducing Catalyst // Catalyst. 2017. Vol. 1. No. 1 (Spring). URL: https://catalystjournal.com/vol1/no1/editorial-robert-brenner (accessed: 01.01.2021).
} 
neo-liberal policy-making, assessing all the above as a virtuous cycle of capitalist growth, centred around the robustness of US capitalism and the capacity of the American empire-state to integrate under its aegis other socio-economic formations, in fact, the entire globe. In this view, the American state is "the author of neo-liberal globalisation", integrating China in its very system, the making of global capitalism having the colours of the American empire-state [Albo, Gindin, Panitch 2010; Panitch, Gindin 2013]. Effectively, financialisation is dealt with as part and parcel of the total circuit of productive capital and not as speculative process relatively dissociated from real commodity production. "This is a false dichotomy", Canadian researches Leo Panitch, Greg Albo and Sam Gindin warn. "Money capital, bank capital, credit and speculative capital are all necessary moments in the circuits of capitalist production and exchange" [Albo, Gindin, Panitch 2010: 33].

We counter that the two phases of the U.S.-led financial statecraft did not remotely match the levels of economic development of the Golden Age of Capitalism. American sociologist Richard Lachmann has recently put it as follows: US growth was much faster and shared far more equitably before 1974 than after. Similarly, Western European GDP enjoyed annual average compound growth rates of 4.08 per cent for 1950-1973 but only 1.78 per cent for 19731998. The comparable figures for Japan are 8.05 per cent and 1.33 per cent. Bretton Woods was successful at limiting if not blocking capital flows and modulating changes in exchange rates, preventing the banking crises that emerged after 1970 with unrestrained speculation in currencies and the enormous growth in "hot money". Worldwide, there were at least 124 financial crises from 1970 to 2007 [Lachmann 2020: 359].

Debt is a form of capital, but it is fictitious capital. Thus, although it is not a "superstructure" of the real process of capital accumulation and development it should not be confused with them. As German philosopher Karl Marx put it, "in the way that even an accumulation of debts can appear an accumulation of capital, we see the distortion involved in the credit system reach its culmination" [Marx 1894/1991: 607-608]. Thus, I argue that neoliberal financial statecraft and the unsustainable levels of debt incurred in its second phase of evolution (1991 onwards) represent a major vulnerability of American capitalism and of the transatlantic core it leads geopolitically. As many Marxist and non-Marxist commentators have remarked from very early days, this vulnerability, has been long and protracted, dating back to the 1960s [Mandel 1969, 1972, 1975; Gilpin 2001; Frank 1998]. Furthermore, because of the inappropriate measures taken by the polities of the core to address the underlying causes of the Great Recession of 2007-2008, the debt situation got worse.

The augmentation of debt, both public and private, as a percentage of GDP increased exponentially since the 1990s. Further, a key feature of the "stabilisation" packages in the wake of the collapse of the Lehman Brothers in September 2008 was their half-baked Keynesianism (some call it "new consensus macroeconomics), i.e. monetary bail-outs for large global and national corporations in the financial and banking sectors, while dropping the interest rates to near-zero and allowing a timid industrial policy, often via trade protectionism ${ }^{4}$.

Thus, enterprises continued their profiteering and speculative activities by financialising their profits, instead of investing them into material production, the result being further drops in industrial output and a pilling up of debt, including consumer debt. Since 2008, the debt increased exponentially in every single economic sector (government, household, non-financial corporate, financial corporate). In 2019, global debt was over 260 trillion USD, or $325 \%$ of global GDP. By comparison, in 2012 the figure was 207 trillion USD, or $300 \%$ of global GDP ${ }^{5}$.

4 Mavroudeas S. Economic crisis and the crisis of economics // Herodox Economists. September 20, 2019. URL: https://heterodox.economicblogs.org/stavrosmavroudeas-blog/2019/mavroudeas-economic-crisis-crisiseconomics-political-economy-credible-video-lecture-smavroudeas (accessed: 17.05.2020). See also: [Arestis 2009].

5 Tiftik E., Mahmood K. High and rising debt levels: should we worry? // Institute of International Finance. 
If we look at government debt, then matters are more revealing. The USA tops the list holding the world's $31 \%$ of government debt, or $104.3 \%$ of its GDP, i.e. 21,465 bln USD. It is followed by Japan (17\%) and China (9.8\%), but these two countries' government debt, especially China's, is largely due to financing of its state-owned enterprises (see below) [Fouskas, Roy-Mukherjee, Huang, Udeogu 2021]. COVID-19 increased debt at astonishing levels in 2020: the IMF has estimated that across the "advanced" countries, gross government debt will rise to 66 trillion USD, or $122 \%$ of GDP, an increase of $17 \%$, and with the USA running a deficit of $15 \%$. Overall, contrary to what had been the case in the 1970s and 1980s when the debt was primarily an affair of the "global South", the world's debt today is mostly held by the "advanced" economies $(75.4 \%)^{7}$.

If lower - and, indeed, near-zero since 2009 - interest rates do not bring about lower debt levels relative to GDP, it means that investors benefitting from this favourable economic climate direct their profits to speculative profiteering rather than material production and job creation. Effectively, it means that the low levels of industrial production, the high concentration of economic activity in services and consumption, hence the disabling of the production of real use and exchange values are responsible for the large government debt in the "advanced" economies. Growth becomes driven by bubbles generated in banking and financial services. Characteristically, the citystate of Singapore, an off-shore financial services economy par excellence and the largest logistics centre in the world has accumulated large amounts of government debt ${ }^{8}$.

Furthermore, "gig" and precarious work have since the 1980s proliferated [Chen 2020: 122-142]. The breakdown of the Fordist /

August 2019. URL: https://www.iif.com/Portals/0/Files/ content/GDM_July2019_vf3.pdf (accessed: 21.02.2020).

6 After the disease, the debt // The Economist. April 25 - May 1, 2020. P. 15.

7 General government gross debt, per cent of GDP // IMF. 2019. URL: https://www.imf.org/external/ datamapper/GGXWDG_NGDP@WEO/OEMDC/ADVEC/ WEOWORLD (accessed: 23.04.2020).

${ }^{8}$ Ibid.
Keynesian consensus brought about not just a proliferation of part-time and flexible work, but also, especially after the Great Recession, a deepening of the process of exploitation and formal / informal subsumption of labour to capital via "gig" work and zero-time contracts. In Anglo-American neo-liberal contexts, the welfare state was further retrenched and large services of it, especially in the UK, were privatised. In ordoliberal Eurozone, the situation took on an unprecedented turn.

\section{The Ordoliberal EU}

Ordoliberalism is a form of supply-side economics that pertains to the German-Austrian model of capitalism. It is far more disciplinarian and rule-based and defines a rigid de-politicisation of the economic on the basis of a strict independence of the central banking mechanism. Literature on ordoliberalism assets that Germany has over the decades managed to transpose this model over the EU / Eurozone via a set of Treaties since the Single European Act of 1986 [Dyson, Featherstone 1999; Bonefeld 2017; Fouskas, Roy-Mukherjee 2019; Fouskas, Gökay, 2019].

The global financial crisis of 2007-2008 contaminated the ordoliberal EU via the banking sector, as many French and German banks were exposed to Anglo-American financial products [Lapavitsas, Kaltenbrunner, Lindo, Michell, Painceira et al. 2010; Fouskas, Dimoulas 2012]. The introduction of the European Monetary Union (EMU) in 1999 (2001 for Greece) turned the banks and the financial system of the region into a hotbed of speculation. The EMU widened the pre-existing gap between European core (surplus countries) and periphery (deficit countries) but, before the crisis, the economies of the periphery operated as platforms of inflows and outflows of cheap money. When the Great Recession brought about a sudden stop across the transatlantic banking sector, the banks, in order to avoid bankruptcy and de-leverage, turned to governments asking them to socialise their liabilities. The German and French governments obeyed and began forging repayments on periphery via humiliating bailout agreements.

The absurdity of these agreements is mainly twofold: first, they displaced the crisis from the 
core to the periphery (Ireland, Greece, Spain and Portugal); second, they transferred the liabilities from private to public institutions "socialising" them and making them "sovereign" - hence the adage "sovereign debt crisis". Thus, the periphery ended up paying for the banking crisis of the core through harsh austerity packages. But this did not happen only in order to buttress the political elites and institutions of the EU and the core states and save the banking system and the Eurozone from total collapse. This is only the internal competitive constraint. Because the EU is both a single market and a customs union whereas most of its members operate via a common currency, it competes in global markets with the USA, Japan and China.

Thus, the ordoliberal Treaties of the EU had had to be reformed and inject even more austerity and discipline in the co-federated members-states and that is how harsh austerity has become a permanent trait of the EU / Eurozone. It is, therefore, also the external combined competitive constraint articulated between the EU, China, Japan and the USA that necessitated the introduction of such unprecedented neo-colonial treaties as the Fiscal Compact and the European Semester programme on the part of the European Commission.

Thus, in order to keep a competitive edge in the global division of labour, the central institutions of the EU are forced to defend the centrality of Germany in the Eurozone, hence its ordoliberal / neo-mercantilist growth model of "low wages, low inflation, export-led". These are the roots of what the British academician Bob Jessop calls enduring austerity post-2008, a concept that tangles-up well with precarious and "gig" labour markets and a lackluster process of capital accumulation across the economies of the core as their nonchalant levels of GDP growth indicate [Fouskas, Roy-Mukherjee 2019]. Contrary to China's pro-Keynesian turn after the Great Recession, between 2010 and 2019 the Eurozone and the USA "cut their public spending-to-GDP ratios by about $3.5 \% \ldots$ Britain's fell by $6 \%$. Taxation, meanwhile, rose by between $1 \%$ and $2 \%$ of GDP" 9 .

9 Tomlinson D., Corbett A. The nature of selfemployment in $21 \mathrm{st}$ century Britain and policy
To all intents and purposes, the so-called the "new consensus macroeconomics" did not work. State sponsored capital injections in the wake of the 2008 crisis and other stimuli — such as historically low interest rates - failed to deliver job creation, general welfare and sustainable development — they only soared up fiscal deficits. As if the Great Recession never happened, the neo-liberal governorates of the Left and the Right across the Euro-Atlantic area continued implementing supply-side policies coupled with massive dosages of authoritarianism in order to sustain harsh austerity measures, hoping to address challenges stemming from the global competitive constraint of UCD [Fouskas, Gökay 2019]. It is under these conditions that flare-up all sort of morbid phenomena around the globe, especially in sensitive geopolitical areas, such as the Balkans, the Caucasus, Central Asia and the Middle East.

\section{Final Touches}

When the transatlantic political economies transitioned to neo-liberal financialisation under the aegis of the US state, the expectation was that US economic centrality would be restored via "disintegration", as the American economist Paul Volcker called it, of the international political economy system ${ }^{10}$. Effectively, this meant the dismantling of the Keynesian interventionist state, retrenching social welfare and surrendering labour-power to supply-side economics. Inflation had to be defeated at all costs. It was proved to be a very precarious undertaking. The "back of inflation" was broken but at the expense of massive financial volatility and uncertainty, leading to unsustainable (government) debt levels and periodic crises, the apex of which was the Great Recession of 2008.

implications // Resolution Foundation. February 2017. URL: https://www.resolutionfoundation.org/app/uploads/ 2017/02/Self-employment-presentation.pdf (accessed: 09.04.2020); After the disease, the debt // The Economist. April 25 - May 1, 2020. P. 15.

${ }^{10}$ Volcker P. The Political Economy of the Dollar The Fred Hirsch Lecture, Warwick University // Federal Reserve Bank of New York. November 9, 1978. URL: https:/www.newyorkfed.org/medialibrary/media/research/ quarterly_review/1978v3/v3n4article1.pdf (accessed: 05.05.2020). 
The problematic underlying condition of the financialised capitalism of the transatlantic assemblage is the lack of industrial base producing, reproducing and recycling real commodity values. Herein lies the failure of financialisation to generate satisfactory rates of socio-economic development, undermining productivity. After the Great Recession of 2007-2008, labour productivity in China rose by $7-8 \%$ per year, whereas in the USA was a bare $1 \%$. In the EU productivity growth was worse than the USA, especially in the Eurozone, which "hovered below $1 \%$ " 11 .

Germany is the only country in the transatlantic area that maintains a solid industrial and export-led base, a fact that enables her to lead the Eurozone on the basis of its ordoliberal austerity and deeply disciplinarian model of

${ }^{11}$ Lapavitsas C. The crisis has exposed the absurdities of neoliberalism; that doesn't mean it will destroy it // The Jacobin. March 27, 2020. URL: https://jacobinmag.com/ 2020/03/coronavirus-pandemic-great-recessionneoliberalism (accessed: 23.04.2020). capitalism. Same as neo-liberal austerity bred Brexit and the Trump phenomenon in the UK and the USA respectively, ordoliberal austerity, breeds xenophobic and racist movements across Europe.

As we have seen, this is not because Germany wants to maintain a leading position as creditor in the 27-member bloc (the internal competitive constraint); this is also because of the (external) competitive constraint of China and other Asian producers, which disrupts Germany's primacy in the EU / Eurozone. Thus, it is the structural power of UCD that has been driving the decline of the US economy in a neoliberal financialised context generated by the US state in the 1970s and 1980s in order to tackle the stagflation of the 1970s. The stagflation is the real prelude to America's long and protracted economic decline. We have to come to terms with this decline in a careful and measured manner, so a major global war sanctioning the hegemonic transition from the Euro-Atlantic world to Asian powers is avoided.

Received / Поступила в редакцию: 15.01.2021 Accepted / Принята к публикации: 02.04.2021

\section{References / Библиографический список}

Albo, G., Gindin, S., \& Panitch, L. (2010). In and out of crisis. Oakland: PM Press.

Alele, O. (2020). Financialisation and the rise of consumer debt in the UK [thesis]. London: University of East London.

Arestis, P. (2009). New consensus macroeconomics: A critical appraisal. Working Paper No. 564. New York: The Levy Institute of Bard College and University of Cambridge.

Armstrong, P., Glyn, A., \& Harrison, J. (1984). Capitalism since World War II. The making and break-up of the Great Boom. London: Fontana.

Arrighi, G. (2007). Adam Smith in Beijing. London: Verso.

Bonefeld, W. (2017). The strong state and the free economy. London: Rowman \& Littlefield.

Brenner, R. (2006). The economics of global turbulence. London: Verso.

Callinicos, A. (2009). Imperialism and global political economy. Cambridge: Polity.

Chen, M. (2020). A new world of workers: confronting the gig economy. In: G. Albo \& L. Panitch (Eds.), Socialist register 2020: Beyond market dystopia. New ways of living (pp. 122-142). London: Merlin press.

Dicken, P. (2007). Global shift: Mapping the changing contours of the world. London: Guilford Press.

Dyson, K., \& Featherstone, K. (1999). The road to Maastricht. Oxford: Oxford University Press.

Foster, J.B., \& Magdoff, H. (2009). The great financial crisis. New York: Monthly Review Press.

Fouskas, V.K., \& Dimoulas, C. (2012). The Greek workshop of debt and the failure of the European project. Journal of Balkan and Near Eastern Studies, 14(1), 1-14. https://doi.org/10.1080/19448953.2012.656929

Fouskas, V.K., \& Gökay, B. (2005). The new American imperialism. Bush's War on Terror and blood for oil. Connecticut: Praeger.

Fouskas, V.K., \& Gökay, B. (2012). The fall of the US empire. Global fault-lines and the shifting imperial order. London: Pluto.

Fouskas, V.K., \& Gökay, B. (2019). The disintegration of Euro-Atlanticism and new authoritarianism. Global power-shift. London, New York: Palgrave Macmillan. 
Fouskas, V.K., \& Roy-Mukherjee, S. (2019). Neo-liberalism and ordoliberalism: one or two critiques? An introduction. Critical Sociology, 45(7-8), 967-982. https://doi.org/10.1177/0896920519835008

Fouskas, V.K., Roy-Mukherjee, S., Huang, Q., \& Udeogu, E. (2021). China \& the USA: globalisation and the decline of America's supremacy. London, New York: Palgrave Macmillan.

Frank, A.G. (1998). ReOrient. Global economy in the Asian age. California: University of California Press.

Gilpin, R. (2001). The political economy of international relations. Princeton: Princeton University Press.

Glyn, A. (2007). Capitalism unleashed. Finance, globalisation and welfare. Oxford: Oxford University Press.

Gowa, J. (1983). Closing the gold window. Domestic politics and the end of Bretton Woods. Ithaca: Cornell University Press.

Gowan, P. (1999). The global gamble. Washington's Faustian bid for world dominance. London: Verso.

Hobsbawm, E. (1995). The age of extremes: A history of the world, 1914-1991. London: Abacus.

Lachmann, R. (2020). First-class passenger on a sinking ship. Elite politics and the decline of great powers. London: Verso.

Lapavitsas, C., Kaltenbrunner, A., Lindo, D., Michell, J., Painceira, J.P. et al. (2010). Eurozone crisis: Beggar thyself and thy neighbour. Journal of Balkan and Near Eastern Studies, 12(4), 321-373. https://doi.org/ $10.1080 / 19448953.2010 .510012$

Mandel, E. (1969). Where is America going? New Left Review, 54(1), 3-16.

Mandel, E. (1972). Decline of the dollar. A Marxist view of the monetary crisis. New York: Pathfinder Press.

Mandel, E. (1975). Late capitalism. London: New Left Books.

Marglin, A.S., \& Schor, J. (1992). The Golden age of capitalism. Oxford: Clarendon Press.

Marx, K. (1894/1991). Capital: A critique of political economy. Vol. 3. London: Penguin.

Panitch, L., \& Gindin, S. (2013). The making of modern capitalism. The political economy of American empire. London: Verso.

Rosenberg, J. (2001). The follies of globalisation theory. London: Verso.

Rosenberg, J. (2010). Remarks on Chapter 1 of Trotsky's History of the Russian revolution. Uneven and combined development. Retrieved from https://unevenandcombineddevelopment.wordpress.com/28-2/

Sanchez-Sibony, O. (2014). Red globalisation. The political economy of the Soviet Cold War from Stalin to Khrushchev. Cambridge: Cambridge University Press. https://doi.org/10.1017/CBO9781139628778

Steil, B., \& Litan, R. (2008). Financial statecraft. The role of financial markets in American foreign policy. New Haven: Yale University Press.

Tooze, A. (2015). Deluge. The Great War and the remaking of global order 1916-1931. London: Penguin.

\footnotetext{
About the author: Fouskas Vassilis K. - PhD in European Politics and Economics, Professor of International Relations, Centre for the Study of States, Markets \& People (STAMP), School of Business \& Law, University of East London; ORCID: 0000-0003-3128-6411; e-mail: v.fouskas@uel.ac.uk
}

Сведения об авторе: Фускас Василис $K$. - доктор европейских политических и экономических наук, профессор международных отношений Центра изучения государств, рынков и населения (STAMP), Школа бизнеса и права, Университет Восточного Лондона; ORCID: 0000-0003-3128-6411; e-mail: v.fouskas@uel.ac.uk 